\title{
Engineering-geological conditions of surface mining in Ainskoe gold field and pit wall stability
}

\author{
V.E. Ol'khovatenko ${ }^{1}$ and E.G. Pryanishnikov ${ }^{1}$ \\ ${ }^{1}$ Tomsk State University of Architecture and Building, Tomsk, Russian Federarion
}

\begin{abstract}
The paper presents the estimation of the engineering-geological conditions of the surface mining in Ainskoe gold field. The mechanical-and-physical properties of the rock are described in this paper, and the stability calculations are provided for the pit walls. Recommendations are given for the geoecological safety measures during the surface mining.
\end{abstract}

\section{Introduction}

The exploration of mineral deposits using the surface mining poses a lot of problems related to the geodynamical disbalance of the environment, contamination of the atmosphere, surface and ground waters. The surface mining has an effect on the geological environment resulting in the modification of the stress-strain state of subsurface rocks, instability of pit walls and the development of geological hazards. In this connection, a predictive estimate of the engineering-geological conditions is very important for the surface mining and the stability of pit walls.

The Ainskoe gold field is located in the South part of Urup Island which is the integral part of the Kuril Islands chain. Its natural and climatic factors affecting the surface mining include the climate, geological structure, composition and mechanicaland-physical properties of rocks.

\section{Climate}

The climate on the Kuril Islands is influenced by the Pacific Ocean and the Sea of Okhotsk. The climate on the Kuril Islands is maritime, generally cold with stormy but rather soft winters and short and cold summers. It is also characterized by strong winds, precipitations and fogs observed all the year round.

Urup Island locates in the climatic region of the Kuril Islands with the average annual precipitation of $1418 \mathrm{~mm}$. Winter is rather warm and windy. The transition of the average daily temperature across $0{ }^{\circ} \mathrm{C}$ towards negative values is observed at the end of November and the beginning of December. February is the coldest month in the year with the average temperature range of $-5-$ $7{ }^{\circ} \mathrm{C}$. Thaw periods and cloudiness are typical for the Urup climate. The spring on Urup is cold, rainy and windy. The reverse transition towards the positive temperatures starts in April. A strong snow blanket prevents the soil from freezing.

The average temperature in January is $-4,8{ }^{\circ} \mathrm{C}$, while in August it is $8,4{ }^{\circ} \mathrm{C}$. The minimum and maximum of the annual absolute temperature come to $-19{ }^{\circ} \mathrm{C}$ and $32{ }^{\circ} \mathrm{C}$, respectively. The average annual temperature on Urup is $2,2^{\circ} \mathrm{C}$. According to the long-term observations of the hydrometeorological services, there are 20-29 foggy days per month within the period from May to September, and only in October this number decreases down to 10 days; the number of rainy days per month comes to 11-17. The average monthly temperature in summer does not exceed $10^{\circ} \mathrm{C}$. Autumn begins mildly and is the best season characterized by many clear days. The amount of precipitations is reduced. The average monthly temperature is $5^{0} \mathrm{C}$. The autumn period lasts for $2-$ 2,5 months and covers late September, October and November.

The amount of precipitations during the warm period (April-October) achieves $866 \mathrm{~mm}$, while in the cold period (November-March) it comes to $552 \mathrm{~mm}$. The maximum daily rain precipitation amounts to $221 \mathrm{~mm}$. The number of snow-stormy days is 67 . Northwestern and south-easter winds prevail on Urup having the average annual velocity of 7,8 $\mathrm{m} / \mathrm{s}$. Storm and hurricane winds can achieve $58 \mathrm{~m} / \mathrm{s}$ leading to the building destruction, while narrow beaches and benches are exposed to hurricane tides. In southern Urup, the average water temperature in August is not over $9^{0} \mathrm{C}$, while in February it is $0,5^{\circ} \mathrm{C}$.

\section{Geological structure of Ainskoe gold field}

The following genetic stratigraphic sequence of the rock is involved in the geological structure of Ainskoe gold field:

- $\quad$ Modern quaternary deposits $\left(Q_{\mathrm{III}}\right)$.

- Volcanic-sedimentary and sedimentary deposits of Rybakov formation $\left(\mathrm{N}_{3} \mathrm{rb}\right)$.

- Subvolcanic deposits of Rybakov formation of volcanic andesitic complex $\left(\mathrm{eN}_{3} \mathrm{rb}\right)$.

\footnotetext{
${ }^{1}$ Valentin Ol'khovatenko: igg@tsuab.ru
} 
- Hydrothermally altered rocks.

Quaternary deposits are represented by clayey soils and sandy cobble. They are weak and have no an effect on the pit wall stability. Deposits of Rybakov formation are represented by tuffites characterized by horizontal and oblique (7-10\%) deposits. Subvolcanic deposits of Rybakov formation of volcanic andesitic complex contain andesites, basalts, diorites, shastalites. Hydrothermally altered rocks include quarzites, quartz metasomatites, argillizated rocks and fault breccia. In the tectonic structure of Cainozoic formations, the faulting plays the important part, while folding is present insignificantly. Volcanic-sedimentary and sedimentary deposits of Rybakov formation have a flat monoclinal folding with the north-eastern course that is a favorable factor for the surface mining. The predictive estimate of the pit wall stability of all engineering-geological types of rock determined in the open-pit was accompanied by the detailed investigations of their mechanical-and-physical properties, construction of strength certificates, determination of standard and design values of strength properties.

\section{Determination of strength properties}

The ultimate uniaxial compression strength of rocks is detected by GOST 21153.2-84 using the hydraulic press IP-1000 with the automatic setting of the loading rate and fracture load recording. Compressive tests were carried out for the cylindrical rock samples having $47 \mathrm{~mm}$ diameter. Their end surfaces were polished on the surface-grinding machine. At the same time, the size, cross-sectional area, and the weight of the samples were identified. Compressive tests included the automatic recording of the facture force, $\mathrm{kN}$. The ultimate uniaxial compression strength can be obtained from $\sigma_{c}=K_{h} \frac{\mathrm{P}}{\mathrm{S}} \cdot 10$, where $\sigma_{c}$ is the ultimate uniaxial compression strength, $\mathrm{MPa} ; P$ is the fracture force, $\mathrm{kN} ; S$ is the area of fracture, $\mathrm{cm}^{2} ; K_{h}$ is the dimensionless factor of the sample height equaling to 1,0 at the diameter ratio $\mathrm{m}=2+0,5$. In this work, the dimensionless coefficient is taken from GOST 21153 . 2 84.

The data obtained at the ultimate uniaxial compression strength of rocks in the Ainskoe gold field are presented in Table 1.

According to GOST 21153.3-85, the uniaxial tensile strength can be obtained from $\sigma_{t}=\frac{\mathrm{P}}{\mathrm{S}} \cdot 10 \mathrm{MPa}$, where $P$ is the fracture force, $\mathrm{kN} ; S$ is the area of fracture equaling to the product of the sample diameter by length, $\mathrm{cm}^{2}$.

The uniaxial tensile strength for the arbitrary-shaped samples is obtained from $\sigma_{t}=7,5 \frac{\mathrm{P}}{\mathrm{S}} \cdot \mathrm{K}$, where $P$ is the fracture force, $\mathrm{kN}$; $S$ is the cross-sectional area of the sample, $\mathrm{cm}^{2} ; K$ is the dimensionless scaling factor equaling to 1,00 at $S=(15 \pm) \mathrm{cm}^{2}$. For other $S$ values, the scaling factor $K$ is taken from GOST 21153.3-85.

The strength certificates are constructed in accordance with the results of compressive strength testing as well as the detection of the rock strength properties.

\section{Mechanical-and-physical properties}

The investigation of such strength properties as the angle of internal friction and specific cohesion of soil is of paramount importance in evaluating the engineering-geological conditions of the mineral deposits. These properties are required to calculate the pit wall stability.

The research investigations allow classifying the engineering-geological conditions of rocks in Ainskoe gold field that includes 13 rock types the mechanical-and-physical properties of which are given in Table 1.

Table 1. Mechanical-and-physical properties of rocks in Ainskoe gold field

\begin{tabular}{|l|c|c|c|c|c|}
\hline \multirow{2}{*}{ Types of rock } & \multicolumn{5}{|c|}{ Mechanical-and-physical properties } \\
\cline { 2 - 6 } & $\rho, \mathrm{g} / \mathrm{cm}^{3}$ & $\sigma_{c}, \mathrm{MPa}$ & $\sigma_{t,} \mathrm{MPa}$ & $\varphi$, degree & Cohesion, MPa \\
\hline Psephitic tuffites & $\frac{2,00-2,50}{2,21}$ & $\frac{1,38-26,80}{8,23}$ & $\frac{0,23-4,50}{1,39}$ & $\frac{22-35}{30}$ & $\frac{0,37-8,00}{2,28}$ \\
\hline Psammitic tuffites & $\frac{2,05-2,27}{2,17}$ & $\frac{1,80-36,0}{11,38}$ & $\frac{0,30-6,00}{1,89}$ & $\frac{27-42}{33}$ & $\frac{0,50-2,25}{1,58}$ \\
\hline Silt-rich psammitic tuffites & $\frac{2,37-2,68}{2,52}$ & $\frac{1,79-36,4}{19,09}$ & $\frac{0,29-6,07}{3,18}$ & $\frac{34-36}{35}$ & $\frac{0,42-8,70}{4,56}$ \\
\hline Argillaceous tuffites & $\frac{2,30-2,36}{2,34}$ & $\frac{3,96-16,88}{11,33}$ & $\frac{0,66-2,81}{1,88}$ & $\frac{30-38}{32}$ & $\frac{0,75-5,00}{3,18}$ \\
\hline Argillizated rocks in tuffites & $\frac{2,07-2,59}{2,24}$ & $\frac{1,48-21,0}{6,31}$ & $\frac{0,24-5,32}{1,32}$ & $\frac{25-45}{33}$ & $\frac{0,60-5,80}{1,72}$ \\
\hline $\begin{array}{l}\text { Argillizated rocks in psephitic } \\
\text { tuffites }\end{array}$ & $\frac{2,18-2,42}{2,32}$ & $\frac{0,72-6,19}{3,25}$ & $\frac{0,12-1,26}{0,59}$ & $\frac{29-36}{32}$ & $\underline{0,18-1,75}$ \\
\hline
\end{tabular}




\begin{tabular}{|l|c|c|c|c|c|}
\hline $\begin{array}{l}\text { Argillizated rocks in } \\
\text { psammitic tuffites }\end{array}$ & 2,36 & $\frac{0,72-5,33}{3,02}$ & $\frac{0,12-0,75}{0,43}$ & $\frac{32-34}{33}$ & $\frac{0,18-1,50}{0,84}$ \\
\hline Advanced argillizated rocks & $\frac{1,94-2,53}{2,25}$ & $\frac{2,60-21,50}{8,76}$ & $\frac{0,43-3,50}{1,47}$ & $\frac{30-43}{35}$ & $\frac{0,60-4,30}{2,00}$ \\
\hline Andesites & $\frac{2,39-2,70}{2,26}$ & $\frac{8,13-27,81}{18,68}$ & $\frac{2,32-8,61}{4,19}$ & $\frac{34-40}{35}$ & $\frac{2,00-7,00}{4,85}$ \\
\hline Shastalites & $\frac{2,31-2,40}{2,36}$ & $\frac{2,10-6,72}{3,99}$ & $\frac{0,35-1,12}{0,79}$ & $\frac{27-33}{31}$ & $\frac{0,62-1,75}{1,04}$ \\
\hline Quartz metasomatites & $\frac{2,18-2,32}{2,24}$ & $\frac{2,56-22,37}{12,69}$ & $\frac{0,43-3,71}{2,20}$ & $\frac{38-40}{39}$ & $\frac{0,55-6,00}{2,68}$ \\
\hline Fault breccia & $\frac{2,47-2,63}{2,55}$ & $\frac{2,30-6,60}{4,45}$ & $\frac{0,60-1,10}{0,85}$ & $\frac{0,50-1,50}{39}$ & $\frac{4,00-7,00}{5,50}$ \\
\hline Secondary quartzites & $\frac{2,12-2,25}{2,18}$ & $\frac{14,7-24,10}{19,40}$ & $\frac{2,40-4,00}{3,20}$ & 35 & \\
\hline
\end{tabular}

According to Table 1, secondary quartzites are the strongest, i.e. their uniaxial compression strength ranges from 14,7 to $24,10 \mathrm{MPa}$ at its average value of $19,40 \mathrm{MPa}$. The strength properties of andesites are close to that of secondary quartzites, namely: $18,68 \mathrm{MPa}$ uniaxial compression strength; $35^{\circ}$ angle of internal friction; and 4,85 MPa specific cohesion. Among other tuffites, silt-rich psammitic tuffites possess the highest strength properties, the uniaxial compression strength of which is 19,09 $\mathrm{MPa} ; 35^{\circ}$ angle of internal friction; and 4,56 MPa specific cohesion. Argillizated rocks in psammitic tuffites are characterized by the lowest strength properties, uniaxial compression strength of which does not exceed 5,33 MPa, while its average value of 3,02 $\mathrm{MPa}$. Also, the low uniaxial compression strength of 3,25 MPa is characteristic to psephitic tuffites.

Thus, Table 1 shows that silt-rich psammitic tuffites, andesites and secondary quartzites are the most stable in the pit walls since they possess the highest strength. Less stable are argillizated rocks in psephitic and psammitic tuffites, while psammitic and argillaceous tuffites and advanced argillizated rocks take the intermediate position. It is worth noting that the strength properties of the rock mass differ from that in a rock. Therefore, in calculating the pit wall stability, the reduction factor of the structural rock cohesion is introduced in the design value of specific cohesion. In this work, the reduction factor is calculated using the Fisenko method [3].

\section{Pit wall stability analysis}

The stability analysis of the pit walls is a complex engineering problem connected with the safety of production mining.

In addition, the rationale for the optimum angle of the pit wall defines not only the safety of mining but also its efficiency and the reduction of areas intended for the production mining. The latter defines one of the most important problem such as the sustainable land use.

The computational methods of evaluation of the pit wall stability are based on the limit equilibrium method illustrated in the works of Demin, Ol'khovatenko, Fisenko [1-3] and others. The main quantitative parameter used for the local evaluation and prediction of the slope stability is the stability factor represented by the ratio between the sum of confining and shearing forces acting on the surface of the expected landslide. Taking the engineering-geological conditions of the gold field, a logarithmic spiral is used as a computational method. This method is based on the limit equilibrium method, while the radii with the minimum stability factor are computed for constructing the sliding surface. The design parameters of the rock shear resistance are accepted for each estimated section as weighted average values of the mass computed by the exploratory hole columns typical for each pit wall.

The investigations of mechanical-and-physical properties of rocks allow the determination of their estimated properties that, in turn, are used to compute the pit wall stability. Since the Ainskoe gold field is located in seismic area with the earthquake intensity of 9, the pit wall analysis is carried out accounting for seismic forces. Seismic forces induce the additional horizontal and vertical loads in the rock mass. The contribution of the vertical components to the seismic force is rather small and can be neglected in the stability analysis.

The direction of the horizontal load corresponds to that of the expected landslide, while its value for each slip block equals to the product of the slip block weight by the seismicity coefficient that depends on the estimated seismicity of the Ainskoe gold field.

The earthquake intensity of the Ainskoe gold field is 8 that is taken into account during the stability analysis of the pit walls (Table 2).

Table 2. Results of pit wall stability analysis

\begin{tabular}{|l|c|c|c|c|c|c|c|}
\hline E.L. & Well & Pit & \multicolumn{2}{|c|}{ Weighted design parameters } & \multicolumn{2}{c|}{ Stability factor } \\
\cline { 3 - 6 } & & walls & $v ; \mathrm{kN} / \mathrm{m}^{3}$ & $\varphi$, degree & Cohesion, $\mathrm{kPa}$ & Without seismicity & With seismicity \\
\hline
\end{tabular}




\begin{tabular}{|l|c|c|c|c|c|c|c|}
\hline 82 & 281 & Right & 23,8 & 29,7 & 20,6 & 1,59 & 1,23 \\
\cline { 2 - 7 } & 282 & Left & 23,2 & 31,8 & 25,5 & 1,62 & 1,25 \\
\hline \multirow{2}{*}{90} & 215 & Right & 22,1 & 29,7 & 19,6 & 1,92 & 1,41 \\
\cline { 2 - 7 } & 225 & Left & 28,6 & 28,6 & 18,3 & 1,60 & 1,21 \\
\hline
\end{tabular}

* Exploration line

According to this Table, the stability factor for the right wall (exploration line 82, well 281) is 1,59 and for the left wall it is 1,62 without accounting for the seismicity coefficient. The stability factors for the right and left walls (exploration line 90) are respectively 1,92 and 1,60 . With the account for the seismicity coefficient, the stability factor decreases down to 1,21 for the left wall in the exploration line 90 and 1,23 for the right wall in the exploration line 82 . The stability factor for the right wall in the exploration line 90 is 1,41 . The obtained stability factors are higher than their standard values. Thus, the Ainskoe gold field will be provided with the pit wall stability for the whole period of its mining.

\section{Conclusions}

Geological investigations carried out for the Ainskoe gold field showed that the surface mining depends on the geological structure, composition, bedding and mechanical-and-physical properties of rocks.

The Ainskoe gold field is rich in volcanic-sedimentary and sedimentary deposits of Rybakov formation, subvolcanic deposits of Rybakov formation of volcanic andesitic complex, and hydrothermally altered rocks. These rocks differ by their lithomineralogical composition and strength properties as well. Test results showed that silt-rich psammitic tuffites, andesites and quartz metasomatites are the strongest rocks having 18-19 MPa uniaxial compression strength. Argillizated rocks in psammitic and psephitic tuffites possess the lowest strength properties, the uniaxial compression strength of which does not exceed 6,19 MPa.

The stability of pit walls mostly depends on the natural and climatic factors, geological structure of the gold field and mechanical-and-physical properties of rocks. The seismicity of the area under research also has an effect on it that should be accounted during the surface mining.

It is advisable to monitor the geological conditions of the Ainskoe gold field so as to detect the changes in the stress-strain state of rocks in the pit walls and prevent the development of geological hazards. This will assist in the elimination of the nonequilibrium conditions of the natural and engineering system during the surface mining.

\section{References}

1. A.M. Demin. landslide in pits: analysis and prediction, (Moscow: GEOS) 79, (2009) (in Russian)

2. V.E. Ol'khovatenko. Engineering geology of coal deposits of Kuznetsk Basin, (Tomsk: TSUAB Publ.) 150, (2014) (in Russian)

3. G.L. Fisenko. Stability of pit walls, 2nd edition (Moscow: Nedra) 376, (1965) (in Russian) 